Marchegiano, M., Horne, D. J., Gliozzi, E., Francke, A., Wagner, B. \& Ariztegui, D. 2020. Rapid Late Pleistocene climate change reconstructed from a lacustrine ostracod record in central Italy (Lake Trasimeno, Umbria). Boreas.

https://doi.org/10.1111/bor.12450. ISSN 0300-9483.

Accepted $17^{\text {th }}$ April 2020. This version incorporates minor edits made in proof. Published online (Early View) $1^{\text {st }}$ June 2020.

\title{
Rapid Late Pleistocene climate change reconstructed from a lacustrine ostracod record in central Italy (Lake Trasimeno, Umbria)
}

\author{
MARTA MARCHEGIANO, DAVID J. HORNE, ELSA GLIOZZI, ALEXANDER \\ FRANCKE, BERND WAGNER AND DANIEL ARIZTEGUI
}

This study presents, for the first time, a detailed quantitative reconstruction of winter (January) and summer (July) palaeotemperatures from the Late Pleistocene to Holocene transition in central Italy based on ostracod assemblages in an $8.59 \mathrm{~m}$ long sediment core retrieved in Lake Trasimeno. Of 19 ostracod species recovered, 13 were calibrated according to their living temperature ranges, enabling us to reconstruct mean January and July temperature ranges using the Mutual Ostracod Temperature Range (MOTR) method. The occurrences of Cytheromorpha fuscata and Limnocythere suessenbornensis from 44000 to 25500 cal. a BP showed mean January temperatures at least $7{ }^{\circ} \mathrm{C}$ colder and mean July temperature at least $1{ }^{\circ} \mathrm{C}$ cooler in some intervals compared to present day temperatures. Comparison of the MOTR-derived January minima curve with a Greenland oxygen isotope record (NGRIP) shows a remarkable correlation of warmer Greenland Interstadial and the colder Greenland Stadial events with clear peaks and troughs in the MOTR signal. These correlations were tested successfully by tuning the MOTR curve to the NGRIP record, resulting in an improved age-depth model combining radiocarbon ages with MOTR tie-points. The results demonstrate that a record of rapid climate change in the North Atlantic region is archived in lacustrine ostracod assemblages in central Italy.

Marta Marchegiano (m.marchegiano@imperial.ac.uk), Department of Earth Sciences, University of Geneva, Rue des Maraîchers 13, 1205 Geneva, Switzerland. Present address: Department of Earth Science and Engineering, Imperial College, London, Royal School of Mines, Prince Consort Rd, Kensington, London SW7 2BP, UK;

David J. Horne, School of Geography, Queen Mary University of London, Mile End Road, London E1 4NS, UK;

Elsa Gliozzi, Department of Science, University Roma Tre, Largo S. Leonardo Murialdo, 1, 00146 Rome, Italy;

Alexander Francke, Wollongong Isotope Geochronology Laboratory, School of Earth, Athmosphere, and Life Sciences, University of Wollongong, NSW 2522 Australia;

Bernd Wagner, Institute of Geology and Mineralogy, University of Cologne, Germany;

Daniel Ariztegui, Department of Earth Sciences, University of Geneva, Rue des Maraîchers 13, 1205 Geneva, Switzerland. 
In the light of rapid climate warming at the present day, it has become increasingly important to delineate the impact of the North Hemispheric $(\mathrm{NH})$ forcing on the climate of the Mediterranean Region. Because of its semi-enclosed nature, this area is particularly sensitive to climate change. It is thus fundamental to better assess and quantify the rates and scales of the rapid climate variability induced by $\mathrm{NH}$ forcing.

Because of their often excellent preservation in sediments, abundance and sensitivity to environmental changes, non-marine ostracods have long been considered an invaluable proxy to assess Quaternary climate changes (Horne et al. 2012). Analyses of their relationship to several climatically influenced variables, such as salinity, temperature, water depth and solute chemistry, enable the reconstruction of climate-driven variations in the hydrochemistry and hydrology of waterbodies (e.g. Smith et al. 2003; Horne et al. 2012; Viehberg \& Mesquita-Joanes 2012; Marchegiano et al. 2018, 2019). Many studies have relied on qualitative palaeoenvironmental interpretations, although the ability to carry out quantitative reconstructions has increased, for example with the development of several transfer functions for non-marine ostracods (e.g. Frenzel et al. 2010; Marco-Barba 2010; Pint et al. 2012; Viehberg \& Mesquita-Joanes 2012).

The Mutual Climate Range (MCR) method for reconstructing Quaternary palaeoclimate was established by Atkinson et al. $(1986,1987)$ using Coleoptera, since when the approach has been developed for different groups such as mammals (Lyons 2003; Lopez-Garcia \& Cuenca-Bescos 2010), amphibians and squamate reptiles (e.g. Blain et al. 2009, 2010), terrestrial molluscs (Moine et al. 2002), herpetofauna (Sinka 1993; Holmes et al. 2010), plant macrofossils (Sinka \& Atkinson 1999), pollen (Pross et al. 2000; Pross \& Klotz 2002) and ostracods (Horne 2007). The principle of the MCR approach is to determine the climatic range (usually in terms of mean monthly temperatures for winter and summer) within which a fossil assemblage of organisms could have co-existed when they were alive. It is assumed that climatic factors such as mean monthly air temperature have a significant influence on the geographical distribution of species. The calibration of species is achieved by comparing their geographic distribution with a climate dataset, so as to determine their distribution in "climate space". An advantage of the MCR method is that it does not consider the abundance of species but only their presence, so it can be used even in samples that yield only low numbers of specimens.

Palaeoenvironmental reconstructions based on the $8.59 \mathrm{~m}$ long Co1320 sediment core, covering the last $c .47000 \mathrm{cal}$. years from Lake Trasimeno have recently been the aim of multidisciplinary investigations by Marchegiano et al. $(2018,2019)$. The marine isotope stages (MIS) 3 and 2 have been subject to rapid, abrupt and significant, climate variations, characterized by relatively warm and humid (interstadials) and cold and dry (stadial) periods. This high-frequency climate variability has been indicated by several different proxies (e.g. ice core stable isotope, speleothems and pollen records) and recognized worldwide (Voelker 2002; Abrantes et al. 2012).

Using ostracod assemblages as the main proxy, Marchegiano et al. $(2018,2019)$ detected important changes in the Lake Trasimeno hydrology, pointing out the alternation of humid periods associated with high lake levels and dry periods with shallower/temporary waterbody conditions. In particular, higher lake levels prevailed from c. 44000 to 35700 cal. a BP and from c. 10000 to 9200 cal. a BP, while shallow/ephemeral lacustrine conditions existed from 35700 to $10000 \mathrm{cal}$. a BP.

The aim of the current study was to obtain a quantitative reconstruction of the effects that the North Atlantic climate changes had on central Italy, by comparing our 
mutual ostracod temperature range (MOTR) results from Lake Trasimeno with the Greenland ice-core record (NGRIP $\delta^{18} \mathrm{O}$, North Greenland Ice Project; Rasmussen et al. 2014). In order to achieve a more precise correlation an improvement of our agedepth model was necessary. To this purpose, we tested the possible correlations by tuning our record to the NGRIP record, combining radiometric dating with assumed synchronicity of features of both records.

Study area and methods

\section{Study area}

Lake Trasimeno (latitude $43^{\circ} 09^{\prime} \mathrm{N}$; longitude $12^{\circ} 06^{\prime} \mathrm{E}$, province of Perugia, Umbria) is the largest lacustrine system of central Italy with a surface of c. $128 \mathrm{~km}^{2}$ (Fig. 1). The area is today characterized by a Mediterranean climate, with the maximum rainfall in autumn and a minimum in summer, and with coldest temperatures in January (mean $5{ }^{\circ} \mathrm{C}$ ) and warmest in July (mean $22^{\circ} \mathrm{C}$ ).

The origin and evolution of Lake Trasimeno are related to and driven by the Northern Apennines extensional tectonics since the Early Pliocene (Gasperini et al. 2010). The lake is very shallow (6 m maximum depth) and has a uniform bathymetry (Ludovisi et al. 2005). Because of its endorheic nature, the hydrological system strictly depends on climatic variations, which are mainly governed by the precipitation/evaporation ratio (Dragoni et al. 2012). Above all, the lake level and salinity variations seem to be driven primarily by temporal change in climate (Gambini 1995; Burzigotti et al. 2003; Dragoni et al. 2012; Marchegiano et al. 2018, 2019). Those changes also affect the organisms living in the lake, which react with physiological adaptations and/or in a change of the species assemblages (Elia et al. 2010; Marchegiano et al. 2018, 2019). Lake Trasimeno is considered a mesotrophic to eutrophic lake. Its present total dissolved salinity (TDS) ranges from 0.7 to $0.9 \mathrm{~g} \mathrm{~L}^{-1}$ and $\mathrm{pH}$ values range from 6.9 to 8.7 (Marchegiano et al. 2017). The water has been classified as chloride, sulphate-calcium and magnesium-rich (Marchegiano et al. 2017). Being a polymictic lake, waters are completely mixed throughout the year producing a homogenization of all the physical and chemical parameters (no stratification). However, seasonal changes in precipitation/evaporation ratio cause variations of their values during the year.

\section{Micropalaeontological sample preparation}

The $8.59 \mathrm{~m}$ long sediment core, stored at the University of Cologne (Germany), was subsampled for micropaleontological analyses at $2 \mathrm{~cm}$ intervals (428 in total). After a $1 \mathrm{~h}$ treatment with $5 \% \mathrm{H}_{2} \mathrm{O}_{2}$, aimed to remove the organic matter, samples were sieved with $125 \mu \mathrm{m}$-sieve mesh using deionized water and oven-dried at $40{ }^{\circ} \mathrm{C}$. In each sample, $\sim 300$ ostracods valves (juvenile and adults) were picked and identified under a miscroscope. In the very few samples in which fewer than 300 valves were present, we picked all the shells. Microslides containing the ostracod assemblages are stored at the Department of Earth Sciences of the University of Geneva (Switzerland).

\section{Mutual Ostracod Temperature Range method}

In order to investigate the relationship between temperature and hydrological regime at regional scale, we herein apply the mutual ostracod temperature range (MOTR) method, an MCR method for non-marine ostracods (Horne 2007; Fig. 1). This is a non-analogue method that utilizes all the calibrated species present in an ostracod assemblage, not just those that occur together at the present day (Horne 2007). 
Examples of the application of the MOTR method to palaeoclimatic reconstruction can be found in Horne (2007), Holmes et al. (2010), Horne et al. (2012), Anadón et al. (2012), Bridgland et al. (2013), Whittaker et al. (2013), Bellucci et al. (2014), Langford et al. (2014a, b, 2017), Pint et al. (2015), Cosentino et al. (2017) and Benvenuti et al. (2017).

The MOTR method (Horne 2007) uses temperature ranges of species that have been calibrated by mapping their distributions with DIVA-GIS software (version 7.5) and comparing them with the WorldClim database (version 1.3) (Hijmans et al. 2001). The ostracod distributions have been taken primarily from the Non-marine Ostracod Distribution in Europe (NODE) database integrated with records from other datasets, e.g. for North America (Horne et al. 2012). The reconstruction of the past mean January and July air temperature ranges for specific ostracod assemblages is made following the MCR principle: the overlap of the calibrated temperature ranges (Table 1) of each species present in a given assemblage yields the mutual temperature range for that interval. Fig. 2 shows an example of the application of the method using the assemblage from sample 374 of the Trasimeno sediment core.

The temperature ranges were calculated for all the samples from 7.4 to $3.1 \mathrm{~m}$ depth in the Co1320 Trasimeno core to obtain the palaeotemperature variations during the deposition of the whole sediment succession. The MOTR method could not be applied from 8.6 to 7.5 , from 7.2 to $7.0 \mathrm{~m}$ and for the upper $3.1 \mathrm{~m}$ because of the absence of ostracods and/or calibrated species.

Of the 19 species identified by Marchegiano et al. (2018), 13 could be used to determine mutual mean January and July air temperature ranges (Table 1). Eleven of those used the calibrations of Horne et al. (2012), while two species required new calibrations. For Eucypris mareotica a new calibration was based on a distributional dataset (53 records) compiled from available literature, including living records from Algeria and Spain in the west to Mongolia and western China in the east. In the case of the extinct fossil species Limnocythere suessenbornensis calibration of a living North American species was used. Limnocythere suessenbornensis was recorded by Marchegiano et al. $(2018,2019)$ as L. blankenbergensis, a small limnocytherid species known in Europe in the Lateglacial-Early Holocene deposits of Germany (Diebel 1968; Günther 1987; Griffiths 1995; Pint et al. 2012). Both species were first described by Diebel (1968). Subsequently, Preece et al. (2007) suggested that they represent adults (L. suessenbornensis) and juveniles (L. blankenbergensis) of the same species; this taxonomic opinion was accepted by Whittaker \& Horne (2009). Following examination of their respective type specimens at the Museum für Naturkunde, Berlin, by David J. Horne in 2019, we consider them as synonymous. Limnocythere suessenbornensis was recorded (as L. blankenbergensis) for the first time in Italy in the Co1320 Trasimeno core during the cool and cold periods corresponding to the MIS 3 interstadials and MIS 2 (Marchegiano et al. 2018), but it has never been found living in Europe. As calibration of the temperature range of an extinct species is not possible and as shell size and morphology of $L$. suessenbornensis are very similar to Limnocythere friabilis Benson \& MacDonald 1963, which is common living today in the Great Lakes region of North America (Smith \& Horne 2016), specimens of this species in the Delorme Collection (Canadian Museum of Nature, Gatineau) were examined by David J. Horne in 2016. It is reasonable to consider L. friabilis as the same morphospecies and the closest living relative of $L$. suessenbornensis, and, thus, to apply temperature range calibrations for $L$. friabilis (based on living North American records) to $L$. 
suessenbornensis. A definitive resolution of this taxonomic issue is beyond the scope of this paper.

The distribution of Cyprideis torosa is not sufficiently represented in NODE to allow calibration. As a matter of fact, this species, widespread in brackish waters, was recorded for the first time in fresh waters in the living fauna of Lake Trasimeno (Marchegiano et al. 2017). Taxa not identified to species level (Amnicythere sp, and Ilyocypris sp.) or for which no calibrations are yet available (Trajancypris serrata, Potamocypris paludum and Herpetocypris helenae) were also excluded (see Table 1 for full taxonomic names of all ostracod species mentioned in the text).

\section{Chronology}

The published chronology of core Co1320 shows that the sedimentary record covers the last 47000 cal. years (Fig. 3; Marchegiano et al. 2018). Preliminary inspection of the MOTR results based on this chronology showed that major peaks and troughs of the January temperature reconstruction can be matched with key peaks and troughs of the NGRIP $\delta^{18} \mathrm{O}$ record (Fig. 4). The July minima show a very similar pattern but with lower amplitude difference between peaks and troughs. It seems reasonable to assume that some minor shifting, between NGRIP and MOTR curves, could be explained by variations in the sediment accumulation rate in Lake Trasimeno throughout the interval we are studying. The radiocarbon-based age-depth model (Fig. 3; see Marchegiano et al. 2018 for more details) shows a low sedimentation rate between 10000 and $30000 \mathrm{cal}$. a. BP and a higher rate between 30000 and 50000 cal. a BP (Fig. 5), but it lacks adequate chronological resolution for precise correlations with the high-resolution NGRIP record. We therefore tested the apparent correlations by tuning the MOTR January minima record to the NGRIP $\delta^{18} \mathrm{O}$ record, considering such an approach to be justified by the prior recognition of Greenland icecore rapid climate change features in the Lake Monticchio record (Allen et al. 1999), which satisfies Blaauw's (2012: p. 46) criterion that "Any tuning should be limited to within regions that have independently been shown to pertain to the same climate regime." The two-stage test was designed to determine (i) whether the obvious peaks and troughs in our signal could be matched with the NGRIP signal with minimal adjustments and without omissions, and (ii) whether the resulting tuned signal could be used to produce a new age-depth model (combing radiometric and relative tuningbased dating points) for the Lake Trasimeno core with plausible changes in sediment accumulation rates (Blaauw 2012; Fig. 5). To establish a consistent and reproducible methodology we set three rules for the tuning: (i) positions of selected tie points (peaks or troughs) could be adjusted along the depth/age axis to align with peaks or troughs (as appropriate) on the NGRIP signal; (ii) to maintain the integrity of the MOTR signal no adjustment was allowed along the temperature axis; and (iii) any tiepoints falling within the \pm ranges of radiocarbon ages were restricted to adjustment only within those ranges. A new age-depth model was produced, utilising tuned MOTR tie-points and radiocarbon ages (Figs 4, 5).

The application of a 5-point simple running mean is a method widely used with time-series data method to smooth short-term fluctuations and emphasize long-term trends. Our data set includes inter-sample variability due to different numbers of specimens being counted in different samples and/or vertical sample intervals that encompass different time intervals. In the former case the results of MOTR method may be influenced because in some samples the specimen count was not high enough to detect a rare but significant species. In the latter case, the variability is typically undetectable; in continuous sampling, a standard interval of (e.g.) $2 \mathrm{~cm}$ may represent 
different time intervals in each sample due to variations in sedimentation rate on a finer scale than the age-depth model can resolve. The application of a 5-point simple running mean to our MOTR signal can result in artifacts such as peaks appearing in the smoothed signal where there were troughs in the data (and vice versa). Smoothing a signal may result in "sucking in" or "smearing" of proxy events due to chronological uncertainties (Blaauw 2012), which we consider in our palaeoclimate reconstruction below. For the NGRIP ice-core oxygen isotope signal, with which we compare our MOTR signal, a 20-year average trade-off between the smoothing of noise and the retention of good resolution is considered to be optimal (Rasmussen et al. 2014).

Results

Calibrated temperature ranges of ostracod species

Among all the species recovered in core Co1320, those with the narrowest calibrated temperature ranges are $L$. suessenbornensis (equivalent to $L$. friabilis), Cytheromorpha fuscata, Candona angulata and C. neglecta (Table 1). However, it should be noted that even taxa with broad ranges can play a significant role in determining the mutual temperature range of an assemblage, if the palaeotemperature is in the vicinity of one end or the other of the species' calibrated range.

Limnocythere friabilis is a freshwater, interstitial species living in North America, common in littoral zones of lakes including the Great Lakes (Smith \& Horne 2016). Using records from the Delorme Ostracode Autecological Database (curated by the Canadian Museum of Nature) we have determined the temperature range of living $L$. friabilis (January -15 to $-3{ }^{\circ} \mathrm{C}$, July +16 to $+23{ }^{\circ} \mathrm{C}$ ) and applied it to $L$. suessenbornensis in our MOTR analyses.

Cytheromorpha fuscata has not been found living in present-day Italy, but has been recorded alive in permanent lentic and lotic brackish to freshwater environments in Finland, Poland, Germany and Britain (Sywula 1966, 1971; Hagerman 1967; Usskilat 1975; Savolainen \& Valtonen 1983; Olenska \& Sywula 1988) as well as in Canada (Neale \& Delorme 1985). Horne et al. (2012) define its temperature range as January -27 to $+4{ }^{\circ} \mathrm{C}$ and July +10 to +21 .

Candona angulata lives today in Lake Trasimeno (Marchegiano et al. 2017) and its temperature range is January -5 to $+7{ }^{\circ} \mathrm{C}$ and July +16 to $+25^{\circ} \mathrm{C}$ (Horne et al. 2012).

Candona neglecta is part of the Italian living fauna (Pieri et al. 2009) but has not been found living in Lake Trasimeno (Marchegiano et al. 2017). It has a wider temperature range than the previously mentioned species: January -10 to $+13{ }^{\circ} \mathrm{C}$ and July +7 to $+27{ }^{\circ} \mathrm{C}$ (Horne et al. 2012).

Sarscypridopsis aculeata, Heterocypris salina, Limnocythere inopinata and Eucypris mareotica have wide temperature ranges (Table 1). In the Lake Trasimeno palaeoenvironmental reconstruction (Marchegiano et al. 2018), these four species were interpreted as indicators of mainly temporary/ephemeral lacustrine conditions, as suggested by their capacity to survive dry intervals in a torpid stage and/or as resting eggs. Moreover the first two of these four species are typically found in brackish environments (Margalef 1956; De Deckker 1981; Mezquita et al. 1999) and the others are tolerant of brackish water. Limnocythere inopinata can tolerate seasonal desiccation and a wide range of salinities; it is found associated with high alkaline water depleted in $\mathrm{Ca}^{+}$(Keatings et al. 2010). E. mareotica is able to inhabit both fresh and highly saline waters up to 110 per mil (Löffler 1990; Aladin et al. 2008). 


\section{MOTR application}

The MOTR method reconstructs ranges, represented by maximum and minimum values, of mean January and mean July air temperature. The actual temperatures may be anywhere between the maxima and minima of the reconstructed ranges. However, it is not possible to attribute greater probability to, e.g., the mean value of the two extremes. The MOTR-based temperature reconstruction from core Co1320 is shown in Fig. 6. The minima curve of the MOTR reconstructed ranges for January and July corresponds well with each other (despite their amplitudes being quite different) in terms of "colder" and "warmer" intervals, as do the maxima curves for January and July. While it is impossible to determine precisely the actual temperatures within the reconstructed ranges, some constraints may at least be discussed. For example the curve for January maxima can be taken to represent a coldness threshold (i.e. it was at least as cold as this) to compare with present-day mean January air temperature. This shows that some periods, particularly in the lower half of the core $(44,000$ to 25,500 cal. a BP), show mean temperatures at least a few degrees colder than today. These periods are mainly determined by the occurrence of $C$. fuscata and $L$. suessenbornensis, which were particularly significant in determining colder winter and summers, with mean January temperature at least $7{ }^{\circ} \mathrm{C}$ colder and mean July temperature at least $1{ }^{\circ} \mathrm{C}$ cooler. However, the July and January maxima curves often show higher-than-present-day temperatures, particularly during the MIS 2, and this is unlikely. We consider that during cold climate stages in southern Europe it is the minima (representing the northern limits of species' ranges), rather than the maxima (representing southern limits of ranges), that will reflect the actual palaeotemperatures most closely, because the species were living close to their northern distributional limits.

Supported by our radiocarbon-based chronology the tuned MOTR January minima record allows the identification of Greenland stadials and interstadials 1-11 as well as the Younger Dryas stadial in the Lake Trasimeno record (Fig. 4). Comparison between the tuned and untuned MOTR curves suggests lower lake sediment accumulation rates between 27000 and 15000 cal. a BP, consistent with the radiocarbon age-depth model. The new, higher-resolution age-depth model (Fig. 5) shows relatively minor deviations from the model based solely on radiocarbon ages and no changes in sediment accumulation rate are evident. The highest accumulation rate is seen between $c$. 7.5 and $6.6 \mathrm{~m}$ depth (Fig. 5), where a distinctive sand unit (c. $7.0-6.8 \mathrm{~m}$ ) has excluded from the profile prior to age-depth modelling in Marchegiano et al. (2018). This unit was deposited during an interval of fluctuating lake levels (Marchegiano et al. 2018) and presumably represents relatively rapid deposition. The tuned signal supports the correlations suggested by Marchegiano et al. (2018: fig. 12) although application of our improved age-depth model may result in minor adjustments.

\section{Discussion}

The analysed core encompasses an interval (c. 47 000-9000 cal. a BP) spanning a long mild period (MIS 3), a cold and dry phase (MIS 2) and the Holocene transition (Termination 1). The MIS 3 and MIS 2 intervals are known to be characterized by high-frequency climate variations consisting of cycles of warmer (interstadial) and colder (stadial) periods (Abrantes et al. 2012). These climate changes have been previously identified in the Lake Trasimeno sediment record (Marchegiano et al. 2018). This study showed that the Lake Trasimeno ostracod faunas responded to and 
recorded climatic variations with important qualitative changes in their assemblages. In detail, three main associations were recognized: i) Cyprideis torosa association indicating a permanent lake with high lake levels and low salinity conditions; ii) Sarscypridopsis aculeata association linked to very shallow/temporary waterbody conditions, and iii) Sarscypridopsis aculeata - Eucypris mareotica association indicating temporary waterbodies affected by high salinity. Variations in TDS are likely due to changes in precipitation/evaporation ratio, as suggested by previous studies (Ludovisi \& Gaino 2010). A change in solute composition is unlikely as Lake Trasimeno has very few tributaries and the groundwater contributes only c. $2.5 \%$ to the total water input (Arpa Umbria 2005).

In Fig. 6 the MOTR-derived curves are compared to the ostracod assemblages recognized by Marchegiano et al. (2018) throughout the core. The tight correlation between the MOTR-derived curve and the reconstructed lake level variations at Lake Trasimeno can be explained by the regional connection between the moisture and the temperature regimes, in which humid conditions correspond to warmer periods and dry intervals to colder ones. This study thus confirms what was previously indicated by several palynological studies (summarized in Fletcher et al. 2010) that in central Italy the interstadials are characterized by humid conditions, whereas dry ones prevailed during stadials.

The MOTR method could not be applied to the interval from $c .47000-44000$ cal. a BP because of the absence of ostracods and of calibrated species. From $c .47000$ to c. $45400 \mathrm{cal}$. a BP the absence of ostracods is probably due to a very low carbonate concentration in the lake water that prevents the ostracods from secreting their calcium carbonate shell (Marchegiano et al. 2018). The humid conditions recorded for this interval, with the consequent increased precipitation, resulted in more diluted lake water (Marchegiano et al. 2018). From c. 45400 to $c .44000$ to cal. a BP the ostracod assemblage is monospecific, with the only occurrence of $C$. torosa a species, as already explained, that has been not calibrated yet.

From c. 44 000-25 500 cal. a BP (Fig. 6) the Lake Trasimeno ostracod record indicates high lake level conditions. During this period, $C$. fuscata and $L$. suessenbornensis/friabilis, the coldest species, both of which are thought to require permanent waters (Curry \& Baker 2000), are significant components of the ostracod assemblages. In contrast, the period c. 25 500-9000 cal. a BP (Fig. 6) is characterized by prolonged dry conditions that caused a strong reduction of the lake waterbody to possible temporary pools (Marchegiano et al. 2018). In this interval, the persistence of $S$. aculeata (a species tolerant of brackish water and with desiccation-resistant eggs, adapted to life in ephemeral waterbodies) is significant, while $C$. fuscata is completely absent and L. suessenbornensis occurs only sporadically. It is noteworthy that despite their absence, the MOTR-derived curves continue to record a strong relationship between local and NGRIP temperatures variations (Fig. 4). This demonstrates that all the ostracod species present in an interval, contribute to the MOTR result and not only those ones tolerating a narrow range of temperatures.

\section{Comparison with other records}

The millennial-scale climatic changes that characterized the North Atlantic during the last glaciation were firstly recognized in the ice-core record from Greenland (Johnsen et al. 1992; Grootes \& Stuiver 1997) and found thereafter in climatic records all over the world (Voelker 2002). The synchronous responses to these events in Mediterranean area were detected in several lacustrine and marine records using a wide range of proxies (e.g. Cacho et al. 1999; Drysdale et al. 2007; Wagner et al. 
2010; Regattieri et al. 2014, 2017). A prompt response was found in the vegetation records analysed, among the most recent, at Lake Ohrid (Macedonia; Sinopoli et al. 2018), Lake Prespa (Greece; Panagiotopoulos 2014) Tenaghi Philippon (Greece; Milner et al. 2016) and Abric Romaní (northeast Iberia; Biltekin et al. 2019). However, none of these studies showed a continuous and/or direct reconstruction of temperatures. To our knowledge, the only pollen-derived mean January air temperature reconstruction comes from Lago Grande di Monticchio (Allen et al. 1999), which is located approximately $375 \mathrm{~km}$ southeast of Lake Trasimeno. In the record from Lago Grande di Monticchio, stadial and interstadial events derived from the January mean temperature curve (Allen et al. 1999) are less pronounced than in Lake Trasimeno. However, the Monticchio January mean $T$ curve, ranging from -15 to $0{ }^{\circ} \mathrm{C}$, would fit within the January MOTR minima and maxima, consistent with the interpretation that the actual temperatures lay somewhere between the extremes of the MOTR ranges.

Although the MOTR method has frequently been applied to infer past climatic conditions, this is the first time it has been used successfully to produce continuous palaeotemperatures data over a long time interval. Anadon et al. (2012) used the MOTR method to reconstruct mean values curves for discrete, discontinuous, midPleistocene to Holocene core intervals from Valle di Castiglione near Rome, Italy, rather than maxima and minima as used in our study. The MOTR method is capable of reconstructing only ranges within which the real temperature existed, and considering mean values of the maxima and minima to be more likely to represent the actual temperatures is regarded as unjustified and inadvisable (Horne \& Mezquita 2008; Horne et al. 2012).

\section{Conclusions}

The application of the MOTR method to the Lake Trasimeno ostracod record between 44000 and 9000 cal. a BP demonstrates for the first time the ability of the method to provide a continuous record of rapid climate change. Comparison between MOTRderived curves and the ostracod record (Marchegiano et al. 2018) proves the presence of relatively rapid variability between warm and humid and cold and dry periods in central Italy during the MIS 3 and MIS 2. The correlation of the tuned MOTR reconstruction with the Younger Dryas and Greenland stadial (GS) and interstadials (GI) 1-11 confirms a southern European (Mediterranean) record of rapid environmental change during this interval, previously recognized using pollen-based methods elsewhere in Italy.

Acknowledgements. - We would like to thank the Foundation Ernst \& Lucie Schmidheiny (Geneva, Switzerland) for the financial support to Marta Marchegiano during her stay at Queen Mary University of London (UK). Also, the grant to Dipartimento di Scienze, Università degli Studi Roma Tre (MIUR-Italy Dipartimenti di Eccellenza, articolo 1, commi 314-337 legge 232/2016) is gratefully acknowledged. We thank two reviewers, Jonathan Holmes and Finn Viehberg, for their constructive comments which greatly helped us to improve this paper.

Author contributions. - MM developed the general idea and conducted the research. DJH developed the idea on how to improve the age model. MM and DJH carried out the interpretation of the data. AF and $\mathrm{BW}$ provided the core material. $\mathrm{EG}, \mathrm{AF}, \mathrm{BW}$ 
and DA sustained the interpretation of the data. M.M wrote the text with the contribution from all authors.

\section{References}

Abrantes, F., Voelker, A. Helga L., Sierro, F. J., Naughton, F., Rodrigues, T., Cacho, I., Ariztegui, D., Brayshaw, D., Sicre, M. \& Batista, L. 2012: Palaeoclimate Variability in the Mediterranean Region. In Lionello, P (eds.): The Climate of the Mediterranean Region, 1-86. Elsevier, London.

Aladin, N., Micklin, P. \& Plotnikov, I. 2008: Biodiversity of the Aral Sea and its importance to the possible ways of rehabilitating and conserving its remnant water bodies. In Qi, J. \& Evered K. T. (eds.): Environmental Problems of Central Asia and Their Economic, Social and Security Impacts, 73-98. NATO Science for Peace and Security Series C: Environmental Security. Springer, Dordrecht.

Allen, J. R., Brandt, U., Brauer, A., Hubberten, H., Huntley, B., Keller, J., Kraml, M., Mackensen, A., Mingram, J., Negendank, J. F.W., Nowaczyk, N. R., Oberhänsli, H., Watts, W. A., Wulf, S. \& Zolitschka, B. 1999: Rapid environmental changes in southern Europe during the last glacial period. Nature 400, 740-743.

Anadon, P., Gliozzi, E. \& Mazzini, I. 2012: Geochemical and palaeoecological analyses of Mid Pleistocene to Holocene ostracod assemblages from Valle di Castiglione (Italy): Palaeoenvironmental and palaeoclimatic assessment. Development in Quaternay Science 17, 217-240.

ARPA Umbria 2005: Gli acquiferi nel bacino del Lago Trasimeno: analisi delle caratteristiche idrogeologiche e idrogeochimiche per la valutazione dei rapporti con il corpo idrico lacustre e l'identificazione di criticità ambientale.45 pp. Monografia/5, Regione Umbria.

Atkinson, T. C., Briffa, K.R., Coope, G. R., Joachim, M. J. \& Perzy, D. W. 1986: Climatic calibration of Coleopteran data. In Berglund, B. E. (eds.): Handbook of Holocene Palaeoecology and Palaeohydrology, 851-858. Wiley, New York.

Atkinson, T. C., Briffa, K. R. \& Coope, G. R. 1987: Seasonal temperatures in Britain during the past 22,000 years, reconstructed using beetle remains. Nature 325, 587-592.

Bellucci, L., Bona, F., Corrado, P., Magri, D., Mazzini, I., Parenti, F., Scardia, G. \& Sardella, R. 2014: Evidence of late Gelasian dispersal of African fauna at Coste San Giacomo (Anagni Basin, central Italy): Early Pleistocene environments and the background of early human occupation in Europe. Quaternary Science Review 96, 72-85.

Benvenuti, M., Bahain, J.J., Capalbo, C., Capretti, C., Ciani, F., D’Amico, C., Esu, D., Giachi, G., Giuliani, C., Gliozzi, E., Lazzeri, S., Macchioni, N., Mariotti Lippi, M., Masini, F., Mazza P. P. A., Pallecchi, P., Revedin, A., Savorelli, A., Spadi, M., Sozzi, L., Vietti, A., Voltaggio, M. \& Aranguren, B. 2017:

Palaeoenvironmental context of the early Neanderthals of Poggetti Vecchi for the late middle Pleistocene of Central Italy. Quaternary Research 88, 327344. 
Biltekin, D., Burjachs, F., Vallverdú, J., Sharp, W. D., Mertz-Kraus, R., Chacon, M. G., Saladie, P., Bischoff, J. L. \& Carbonelli, E. 2019: Vegetation and climate record from Abric Romaní (Capellades, northeast Iberia) during the Upper Pleistocene (MIS 5d-3). Quaternary Science Review 220, 154-164.

Blaauw, M. 2012: Out of tune: the dangers of aligning proxy archives. Quaternary Science Review 36, 38-49.

Blain, H.A., Bailon, S., Cuenca-Bescos, G., Arsuaga, J. L., de Castro, J. M. B. \& Carbonell, E. 2009: Long-term climate record inferred from early-middle Pleistocene amphibian and squamate reptile assemblages at the Gran Dolina Cave, Atapuerca, Spain. Journal of Human Evolution 56, 55-65.

Blain, H.A., Bailon, S., Cuenca-Bescos, G., Bennàsar, M., Rofes, J., Lopez-Garcia, J. M., Huguet, R., Arsuaga, J. L., Bermudez de Castro, J. M. \& Carbonelli, E. 2010: Climate and environment of the earliest West European hominins inferred from amphibian and squamate reptile assemblages: Sima del Elefante Lower Red Unit, Atapuerca, Spain. Quaternary Science Reviews 29, 30343044.

Bridgland, D., Harding, P., Allen, P., Candy, I., Cherry, C., George, W., Horne, D. J., Keen, D., Penkman, K. E., Preece, R., Rhodes, E., Scaife, R., Schreve, D., Schwenninger, J. L., Slipper, I., Ward, G., White, M., White, T. \& Whittaker, J. 2013: An enhanced record of MIS 9 environments, geochronology and geoarchaeology: data from construction of the High Speed 1 (LondonChannel Tunnel) rail-link and other recent investigations at Purfleet, Essex, UK. Proceeding of the Geologists' Association 124, 417-476.

Burzigotti, R., Dragoni, W., Evangelisti, C. \& Gervasi, L. 2003: The role of Lake Trasimeno (central Italy) in the history of hydrology and water management. IWHA 3rd International Conference, Alexandria, Egypt, 11-14.

Cacho, I., Grimalt, J. O., Pelejero, C., Canals, M., Sierro, F. J., Flores, J. A. \& Shackleton, N. J. 1999: Dansgaard-oeschger and Heinrich event imprints in Alboran sea palaeotemperatures. Palaeoceanography 14, 698-705.

Cosentino, D., Asti, R., Nocentini, M., Gliozzi, E., Kotsakis, T., Mattei, M., Esu, D., Spadi, M., Tallini, M. \& Cifelli, F. 2017: New insights into the onset and evolution of the central Apennine extensional intermontane basins based on the tectonically active L'Aquila Basin (central Italy). Geological Society of America Bulletin 129, 1314-1336.

Curry, B. B. \& Baker, R. G., 2000: Palaeohydrology, vegetation, and climate since the late Illinois Episode ( $\sim 130 \mathrm{ka})$ in south-central Illinois. Palaeogeography Palaeoclimatology Palaeoecology 155, 59-81.

De Deckker, P. 1981: Ostracods of athalassic saline lakes. Hydrobiologia 81, 131144.

Diebel, K. 1968: Neue Limnocythere-Arten (Ostracoda) aus dem deutschen Pleistozän. Monatsberichte der Deutschen Akademie der Wissenschaften zu Berlin 10, 519-538.

Dragoni, W., Melillo, M. \& Giontella, C. 2012: Bilancio idrico del lago Trasimeno. In: Martinelli, A. (eds): Tutela Ambientale Del Lago Trasimeno, 69-85. Libri Arpa Umbria, Perugia.

Drysdale, R. N., Zanchetta, G., Hellstrom, J. C., Fallick, A. E., McDonald, J. \& Cartwright, I. 2007: Stalagmite evidence for the precise timing of North Atlantic cold events during the early last glacial. Geology 35, 77-80. 
Elia, A. C., Dörr, A. J. M., Abete, M. C. \& Prearo, M. 2010: Seasonal variability of detoxificant response and heavy metal accumulation in tissues of both sexes in Tinca tinca (L.) from Lake Trasimeno. Reviews in Fish Biology and Fisheries 20, 425-434.

Fletcher, W. J., Sánchez Goñi, M. F., Allen, J. R. M., Cheddadi, R., CombourieuNebout, N., Huntley, B., Lawson, I., Londeix, L., Magri, D., Margari, V., Müller, U. C., Naughton, F., Novenko, E., Roucoux, K. \& Tzedakis, P. C. 2010: Millennial-scale variability during the last glacial in vegetation records from Europe. Quaternary Science Review 29, 2839-2864.

Frenzel, P., Keyser, D. \& Viehberg, F. A. 2010: An illustrated key and (palaeo) ecological primer for Postglacial to Recent Ostracoda (Crustacea) of the Baltic Sea. Boreas 39, 567-575.

Gambini, E. 1995: Le oscillazioni di livello del lago Trasimeno. 139 pp. Quaderni del Museo della Pesca del Lago Trasimeno 2. Grafiche Piemme, Perugia.

Gasperini, L., Barchi, M. R., Bellucci, L. G., Bortoluzzi, G., Ligi, M. \& Pauselli, C. 2010: Tectonostratigraphy of Lake Trasimeno (Italy) and the geological evolution of the Northern Apennines. Tectonophysics 492, 164-174.

Griffiths, H. 1995: European Quaternary Freshwater Ostracoda: a biostratigraphic and palaeobiogeographic primer. Scopolia 34, 1-168.

Grootes, P. M. \& Stuiver, M. 1997: ${ }^{18} \mathrm{O} /{ }^{16} \mathrm{O}$ variability in Greenland snow and ice with 10-3 to 105 year time resolution. Journal of Geophysical Research 102, $26,455-26,470$.

Günther, J. 1987: Ostracod fauna of Duvensee, an ancient lake in Northern Germany. Hydrobiologia 143, 411-416.

Hagerman, L. 1967: Ostracods of the Tvarminne area, Gulf of Finland. Societas Scientiarum Fennica 30, 1-12.

Hijmans, R. J., Guarino, L., Cruz, M. \& Rojas, E. 2001: Computer tools for spatial analysis of plant genetic resources data: 1 DIVA GIS. Plant Genetic Resources Newsletter 127, 15-19.

Holmes, J., Atkinson, T. C., Darbyshire, D. P. F., Horne, D. J., Joordens, J., Roberts, M. B., Sinka, K. \& Whittaker, J. 2010: Middle Pleistocene climate and hydrological environment at the Boxgrove hominin site (West Sussex, UK) from ostracod records. Quaternary Science Review 29, 1515-1527.

Horne, D. J. 2007: A Mutal Temperature Range method for Quaternary palaeoclimatic analysis using European nonmarine Ostracoda. Quaternary Science Review 26, 1398-1415.

Horne, D. J., Curry, B. B. \& Mesquita-Joanes, F. 2012: Mutual climatic range methods for Quaternary ostracods. In Horne, D. J., Holmes, J. A., RodriguezLazaro, J. \& Viehberg, F. A. (eds.): Ostracoda as Proxies for Quaternary Climate Change, 65-84. Developments in Quaternary Science 17. Elsevier, Amsterdam.

Horne, D. J. \& Mezquita, F. 2008: Palaeoclimatic applications of large databases: developing and testing methods of palaeotemperature reconstruction using nonmarine ostracods. Senckenbergiana lethaea 88, (2). 93-112.

Johnsen, S. J., Clausen, H. B., Dansgaard, W., Fuhrer, K., Gundestrup, N. \& Hammer, C. U. 1992: Irregular glacial interstadials recorded in a new Greenland ice core. Nature 359, 311-313. 
Keatings, K., Holmes, J., Flower, R., Horne, D., Whittaker, J. E. \& Abu-Zied, R. H. 2010: Ostracods and the Holocene palaeolimnology of Lake Qarun, with special reference to past human-environment interactions in the Faiyum (Egypt). Hydrobiologia 654, 155-176.

Langford, H., Boreham, S., Briant, R., Coope, G. R., Horne, D. J., Schreve, D., Whittaker, J. \& Whitehouse, N. J. 2014a: Middle to Late Pleistocene palaeoecological reconstructions and palaeotemperature estimates for cold/cool stage deposits at Whittlesey, eastern England. Quaternary International 341, 6-26.

Langford, H., Boreham, S., Coope, G. R., Fletcher, W. J., Horne, D. J., Keen, D., Mighall, T., Penkman, K. E., Schreve, D. \& Whittaker, J. 2014b:

Palaeoecology of a late MIS 7 interglacial deposit from eastern England. Quaternary International 341, 27-45.

Langford, H. E., Boreham, S., Briant, R. M., Coope, G. R., Horne, D. J., Penkman, K. E., Schreve, D. C., Whitehouse, N. J. \& Whittaker, J. 2017: Evidence for the early onset of the Ipswichian thermal optimum: palaeoecology of Last Interglacial deposits at Whittlesey, eastern England. Journal of Geological Society 174, 988-1003.

Löffler, H. 1990: Palaeolimnology of Neusiedlersee, Austria. I. The succession of Ostracods. Hydrobiologia 214, 229-238.

Lopez-Garcia, J. \& Cuenca-Bescos, G. 2010: Late pleistocene climatic evolution in catalonia (northeastern spain) from the small-mammals association. Quaternaire 21, 249-257.

Ludovisi, A., Minozzo, M., Pandolfi, P. \& Taticchi, M. I. 2005: Modelling the horizontal spatial structure of planktonic community in Lake Trasimeno (Umbria, Italy) using multivariate geostatistical methods. Ecological Modelling 181, 247-262.

Ludovisi, A. \& Gaino, E. 2010: Meteorological and water quality changes in Lake Trasimeno (Umbria, Italy) during the last fifty years. Journal of Limnology 69, 174-188.

Lyons, S. K. 2003: A quantitative assessment of the range shifts of Pleistocene mammals. Journal of Mammology 84, 385-402.

Marchegiano, M., Gliozzi, E., Ceschin, S., Mazzini, I., Adatte, T., Mazza, R., Gliozzi, S. \& Ariztegui, D. 2017: Ecology and distribution of living ostracod assemblages in a shallow endorheic lake: the example of the Lake Trasimeno (Umbria, central Italy). Journal of Limnology 76, 469 - 487. https://doi.org/10.4081/jlimnol.2017.1478

Marchegiano, M., Francke, A., Gliozzi, E. \& Ariztegui, D. 2018: Arid and humid phases in central Italy during the Late Pleistocene revealed by the Lake Trasimeno ostracod record. Palaeogeography Palaeoclimatology Palaeoecology 490, 55-69.

Marchegiano, M., Francke, A., Gliozzi, E., Wagner, B. \& Ariztegui, D. 2019: Highresolution palaeohydrological reconstruction of central Italy during the Holocene. The Holocene 29, 481-492.

Marco-Barba, J. 2010: Freshwater ostracods ecology and geochemistry as palaeoenvironmental indicators in marginal marine ecosystems: A case of study the Albufera of Valencia. Ph. D. thesis, University of Valencia, $300 \mathrm{pp}$.

Margalef, R. 1956: La vida en las aquas de elevado residuo salino de provincia de Zamora. P. Instituto Biologia Aplicata 24, 123-137. 
Mezquita, F., Tapia, G. \& Roca, J. R. 1999: Ostracoda from springs on the eastern Iberian Peninsula: ecology, biogeography and palaeolimnological implications. Palaeogeography Palaeoclimatology Palaeoecology 148, 65-85.

Milner, A. M., Roucoux, K. H., Collier, R. E. L., Muller, U. C., Pross, J. \& Tzedakis, P. C. 2016: Vegetation responses to abrupt climatic changes during the Last Interglacial Complex (Marine Isotope Stage 5) at Tenaghi Philippon, NE Greece. Quaternary Science Reviews 154, 169-181.

Moine, O., Rousseau, D. D., Jolly, D. \& Vianey-Liaud, M. 2002: Palaeoclimatic reconstruction using mutual climatic range on terrestrial mollusks. Quaternary Research 57, 162-172.

Neale, J. W. \& Delorme, L. D. 1985: Cytheromorpha Fuscata, a relict Holocene marine ostracod from freshwater inland lakes of Manitoba, Canada. Revista Española de Micropalaeontologia 17, 41-64.

Olenska, M. \& Sywula, T. 1988: Ostracoda (Crustacea) of the Gulf of Gdańsk. 1. Species from the sandy bottom off Rewa. Fragmenta Faunistica Warsaw 31, 445-458.

Panagiotopoulos, K. 2014: Climate variability over the last $92 \mathrm{ka}$ in SW Balkans from analysis of sediments from Lake Prespa. Climate of the Past 10, 643-660.

Pieri, V., Martens, K., Stoch, F. \& Rossetti, G. 2009: Distribution and ecology of nonmarine ostracods (Crustacea, Ostracoda) from Friuli Venezia Giulia (NE Italy). Journal of Limnology 68, 1-15.

Pint, A., Frenzel, P., Fuhrmann, R., Scharf, B. \& Wennrich, V. 2012: Distribution of Cyprideis torosa (Ostracoda) in Quaternary Athalassic Sediments in Germany and its Application for Palaeoecological Reconstructions. International Review of Hydrobiology 97, 330-355.

Pint, A., Frenzel, P., Horne, D. J., Francke, J., Daniel, T., Burghardt, A., Funai, B., Lippold, K., Daut, G. \& Wennrich, V. 2015: Ostracoda from inland waterbodies with saline influence in Central Germany: Implications for palaeoenvironmental reconstruction. Palaeogeography Palaeoclimatology Palaeoecology 419, 37-46.

Preece, R. C., Parfitt, S. A., Bridgland, D. R., Lewis, S. G., Rowe, P. J., Atkinson, T. C., Candy, I., Debenham, N. C., Penkman, K. E. H., Rhodes, E. J., Schwenninger, J-L., Griffiths, H. I., Whittaker, J. E. \& Gleed-Owen, C. 2007: Terrestrial environments during MIS 11: evidence from the Palaeolithic site at West Stow, Suffolk, UK. Quaternary Science Review 26, 1236-1300.

Pross, J., Klotz, S. \& Mosbrugger, V. 2000: Peconstructing palaeotemperatures from the Early and Middle Pleistocene using the mutual climatic range method based on plant fossils. Quaternary Science Review 19, 1785-1799.

Pross, J. \& Klotz, S. 2002: Palaeotemperature calculations from the Praetiglian/Tiglian (Plio-Pleistocene) pollen record of Lieth, northern German: implications for the climatic evolution of NWEurope. Global Planetary Change 34, 253-267.

Rasmussen, S. O., Bigler, M., Blockley, S. P., Blunier, T., Buchardt, S., Clausen, H. B., Cvijanovic, I., Dahl-Jensen, D., Johnsen, S. J., Fischer, H., Gkinis, V., Guillevic, M., Hoek, W. Z., Lowe, J. J., Pedro, J. B., Popp, T., Seierstad, I. K., Steffensen, J. P., Svensson, A. M., Vallelonga, P., Vinther, B. M., Walker, M. J. C., Wheatley, J. J. \& Winstrup, M. 2014: A stratigraphic framework for abrupt climatic changes during the Last Glacial period based on three synchronized Greenland ice-core records: refining and extending the INTIMATE event stratigraphy. Quaternary Science Review 106, 14-28. 
Regattieri, E., Zanchetta, G., Drysdale, R. N., Isola, I., Hellstrom, J. C. \& Roncioni, A. 2014: A continuous stable isotope record from the penultimate glacial maximum to the last interglacial $(159-121 \mathrm{ka})$ from Tana Che Urla Cave (Apuans Alps, Central Italy). Quaternary Research 82, 450-461.

Regattieri, E., Giaccio, B., Nomade, S., Francke, A., Vogel, H., Drysdale, R. N., Perchiazzi, W., Wagner, B., Gemelli, M., Mazzini, I., Boschi, C., Galli, P. \& Peronace, E. 2017: A last interglacial record of environmental changes from the Sulmona basin (Central Italy). Palaeogeography Palaeoclimatology Palaeoecology 472, 51-66.

Savolainen, I. \& Valtonen, T. 1983: Ostracods of the north-eastern Bothnian Bay and population dynamics of the principal species. Aquilo Series Zoologica 22, 6976.

Sinka, K. 1993: Developing the mutual climatic range method of palaeoclimatic reconstruction. Ph.D. thesis, University of East Anglia, 2 vols., 212 \& 113 pp.

Sinka, K. \& Atkinson, T. C. 1999: A mutual climatic range method for reconstructing palaeoclimate from plant remains. Journal of the Geological Society of London 156, 381-396.

Sinopoli, G., Masi, A., Regattieri, E., Wagner, B., Francke, A., Peyron, O. \& Sadori, L. 2018: Palynology of the Last Interglacial Complex at Lake Ohrid: palaeoenvironmental and palaeoclimatic inferences. Quaternary Science Review 180, 177-192.

Smith, A. J., Davis, J. W., Palmer, D. F., Forester, R. M. \& Curry, B. B. 2003: Ostracods as hydrological indicators in springs, streams and wetlands: a tool for environmental and palaeoenvironmental assessment. Paleontological Society Papers 9, 209-222.

Smith, A. J. \& Horne, D. J., 2016: Class Ostracoda, In Thorp, J. \& Rogers, D.C. (eds.): Keys to Nearctic Fauna. Thorp and Covich's Freshwater Invertebrates, 477-514. Elsevier, Amsterdam.

Sywula, T. 1966: Investigations into inland saline areas of Poland, faunistic studies: Ostracoda and Copepoda. Physiographical Researches in Westen Poland 18, $35-65$.

Sywula, T. 1971: Notes on Ostracods 12: New and interesting species from Poland. Bulletin of the Polish Academy of Science 19, 665-670.

Usskilat, F. 1975: Untersuchungen am Oligohalinikum der Schlei: 2. - Die Ostracodengemeinschaften des Haddebyer und Selke Noores (Schlei). Kiel. Meeresforsch 31, 151-178.

Viehberg, F. A. \& Mesquita-Joanes, F. 2012: Quantitative transfer function approaches in palaeoclimatic reconstruction using Quaternary Ostracods. In Horne, D. J., Holmes, J. A., Rodriguez-Lazaro, J. \& Viehberg, F. A. (eds): Ostracoda as Proxies for Quaternary Climate Change, 47-64. Developments in Quaternary Science 17. Elsevier, Amsterdam.

Voelker, A. H. L. 2002: Global distribuition of centennial-scale records for Marine Isotope Stage (MIS) 3: a database. Quaternary Science Review 21, 11851212.

Wagner, B., Vogel, H., Zanchetta, G. \& Sulpizio, R. 2010: Environmental change within the Balkan region during the past c. $50 \mathrm{ka}$ recorded in the sediments from lakes Prespa and Ohrid. Biogeosciences 7, 3187-3198.

Whittaker, J. E. \& Horne, D. J. 2009. Pleistocene. In Whittaker, J. E. \& Hart, M. B. (eds.): Ostracods in British Stratigraphy, 447-467. The

Micropalaeontological Society, Special Publications, vol. 8. 
Whittaker, J., Horne, D. J. \& Wenban-Smith, F. 2013: Ostracods and other microfossils. In Wenban-Smith, F. (ed.): The Ebbsfleet Elephant. Excavations at Southfleet Road, Swanscombe in Advance of High Speed 1, 2003-4. Oxford Archaeology Monograph 20, 275-289. 


\section{FIGURES}

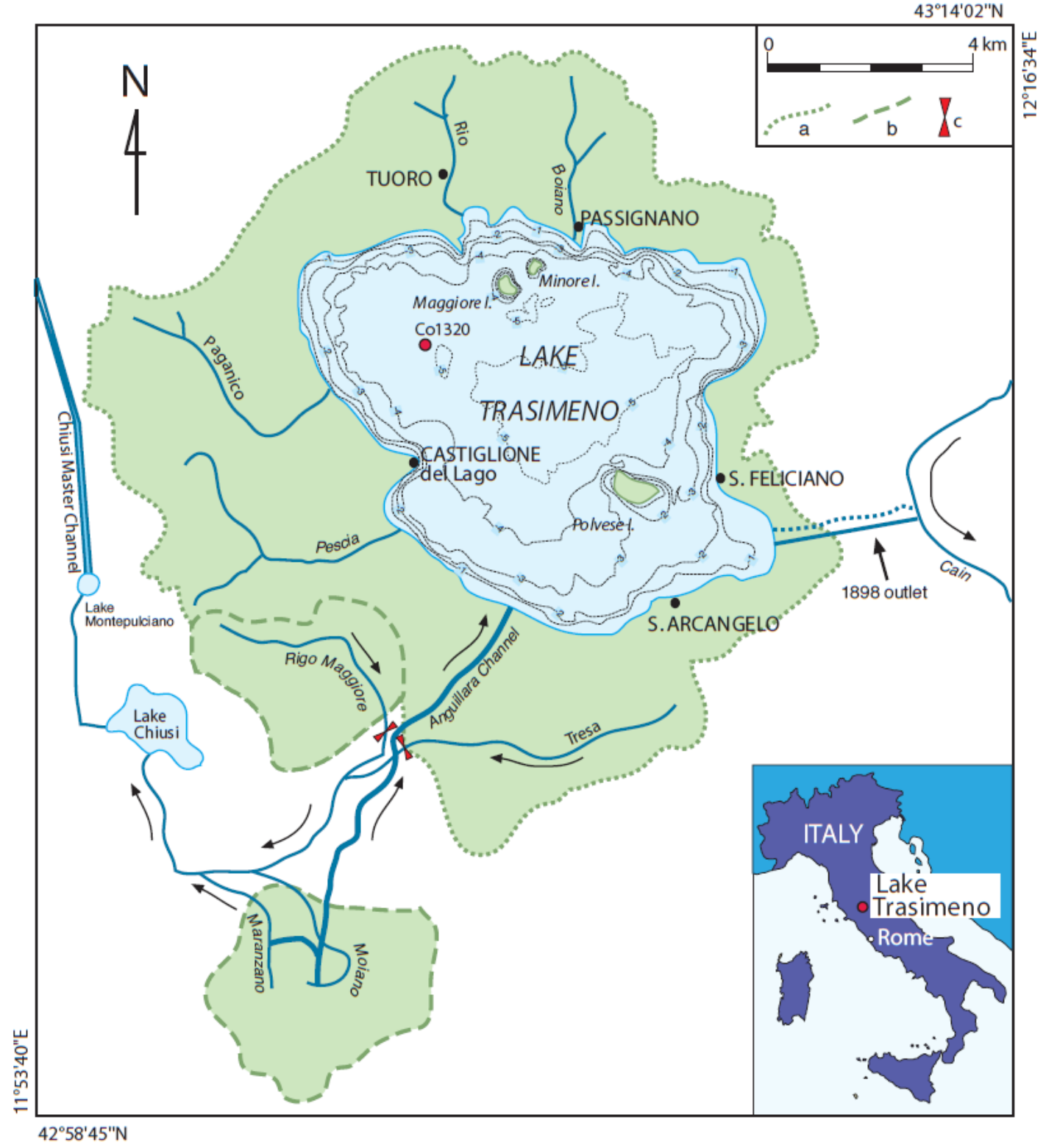

FIG. 1: Map of Lake Trasimeno showing the location of core Co1320. Legend: $\mathrm{a}=$ natural catchment area; $b=$ artificially-joined basins; $c=$ sluice gates of the artificially-joined channels (modified from Marchegiano et al. 2017). 

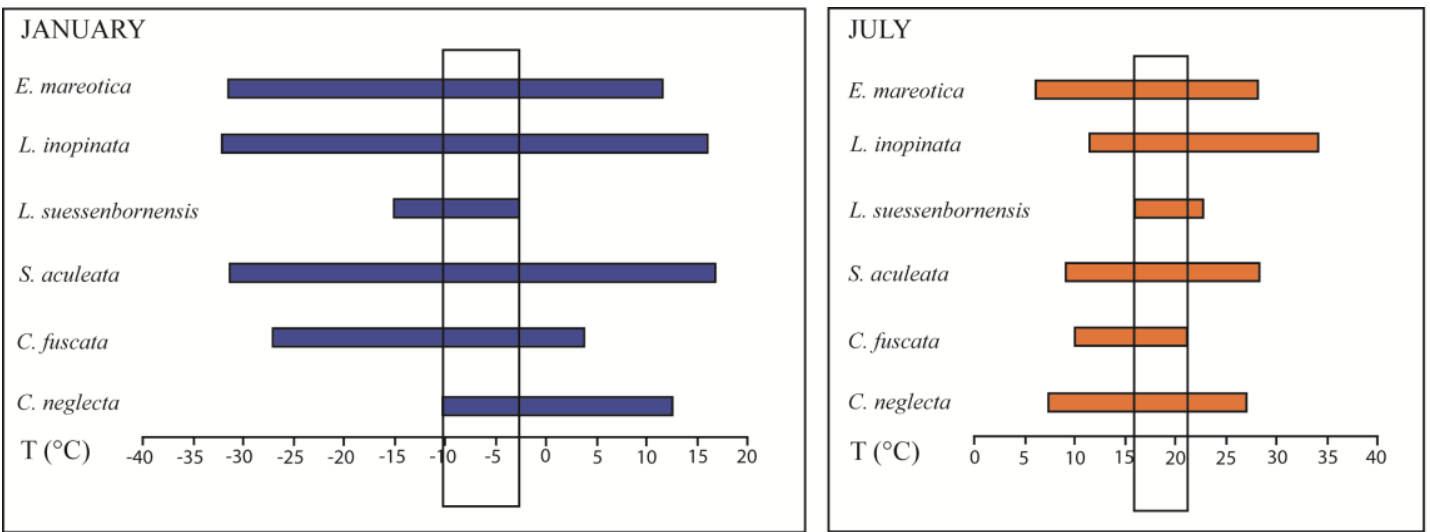

FIG. 2: Example of the application of the MOTR method on sample 374 of core Co1320. The results are: mean January air temperature range -10 to $-3{ }^{\circ} \mathrm{C}$, mean July air temperature range +16 to $+21^{\circ} \mathrm{C}$.

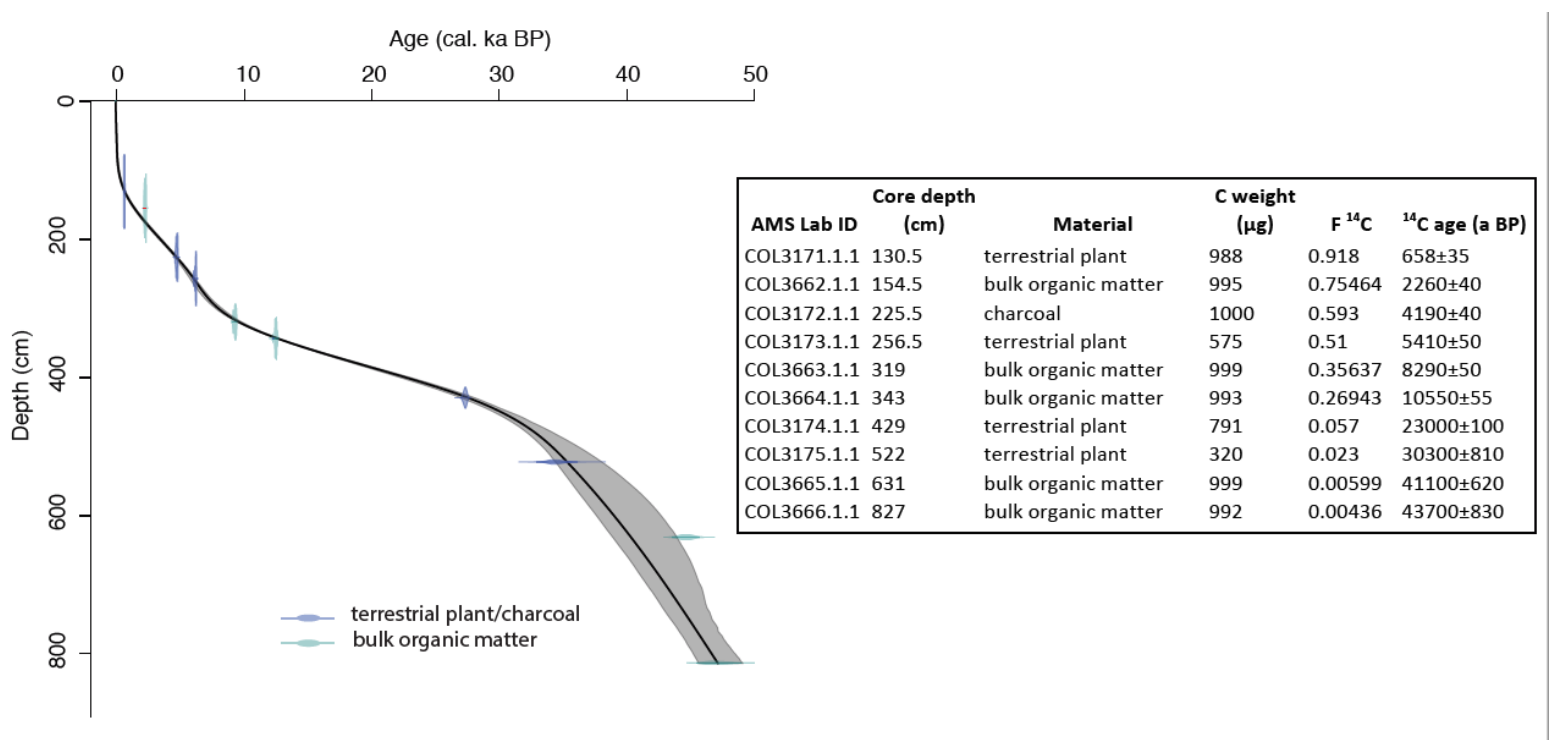

FIG. 3: Age model of core Co1320 (from Marchegiano et al. 2018). 


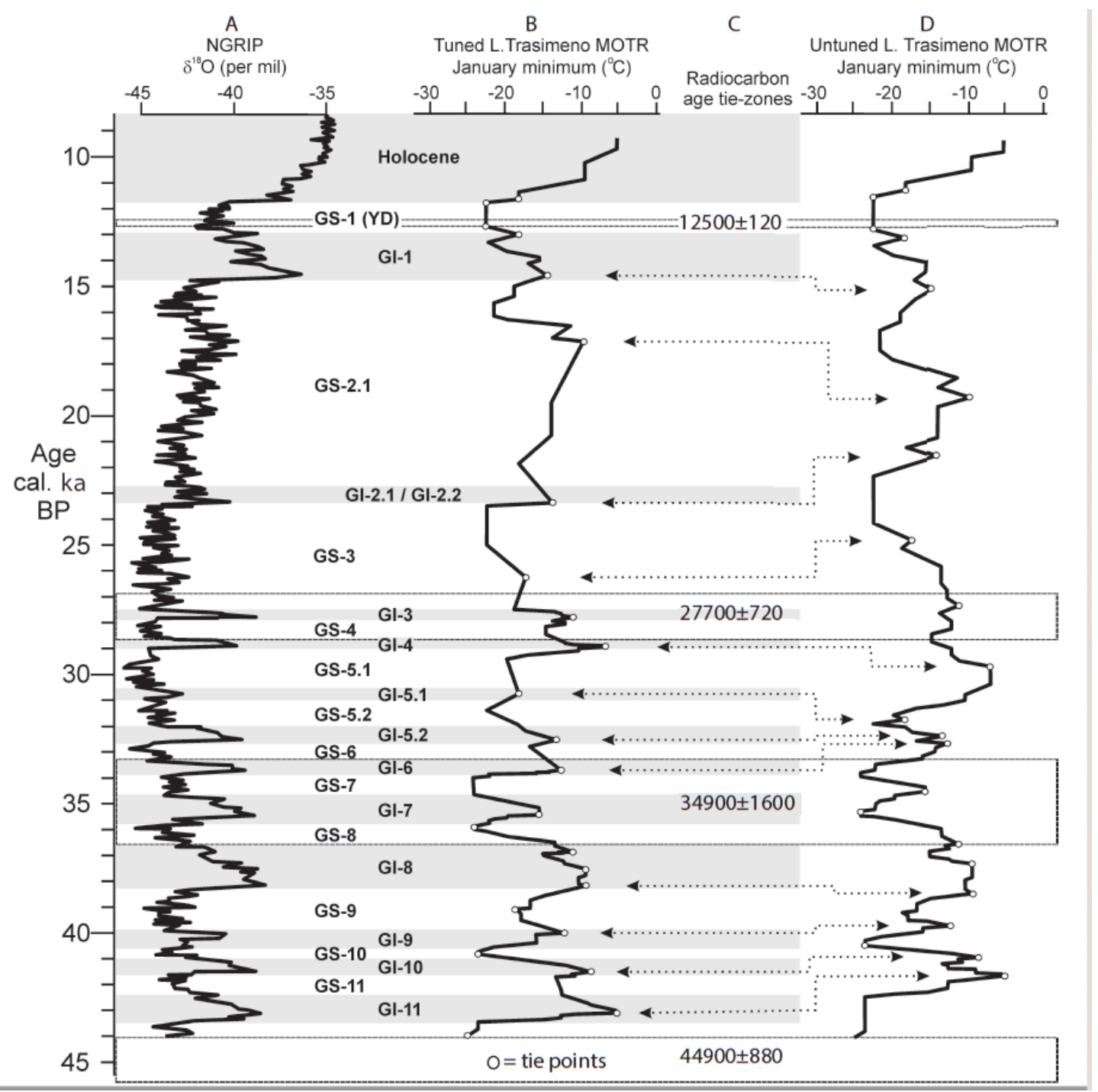

FIG. 4: Comparison between Lake Trasimeno tuned (B) and untuned (D) MOTR January minima (five-point moving averages) and the Greenland (NGRIP) oxygen stable isotope record (A). Radiocarbon age tie-zones are also indicated (C). 


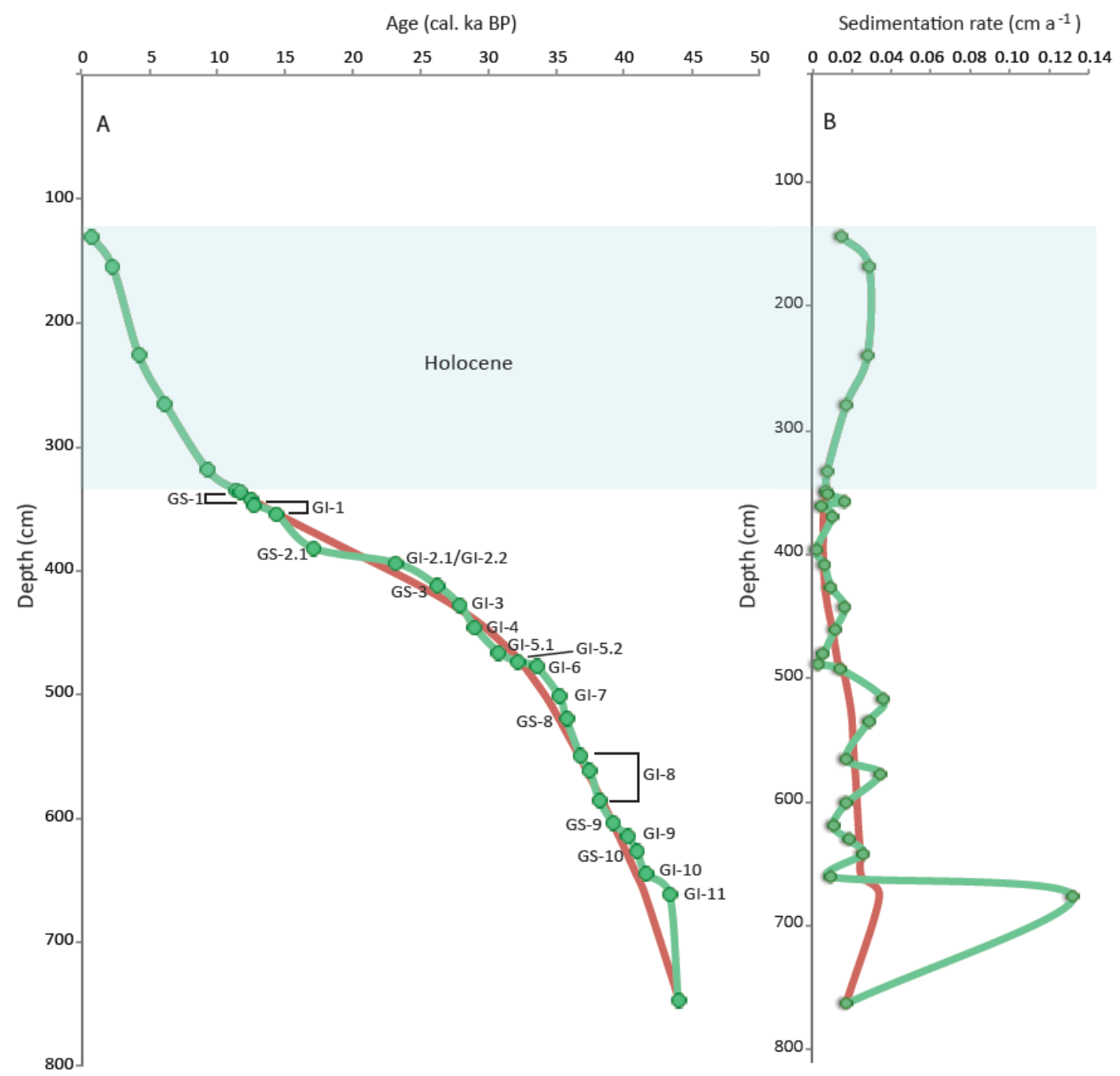

Fig. 5: A. New age-depth model produced (green curve), utilising tuned MOTR tiepoints (showed in Fig. 4) and radiocarbon ages. The red curve indicates the previous age model reconstructed using only radiocarbon ages (Marchegiano et al. 2018). B. Calculated sedimentation rate for the tuned (green curve) and the un-tuned (red curve) age model. 


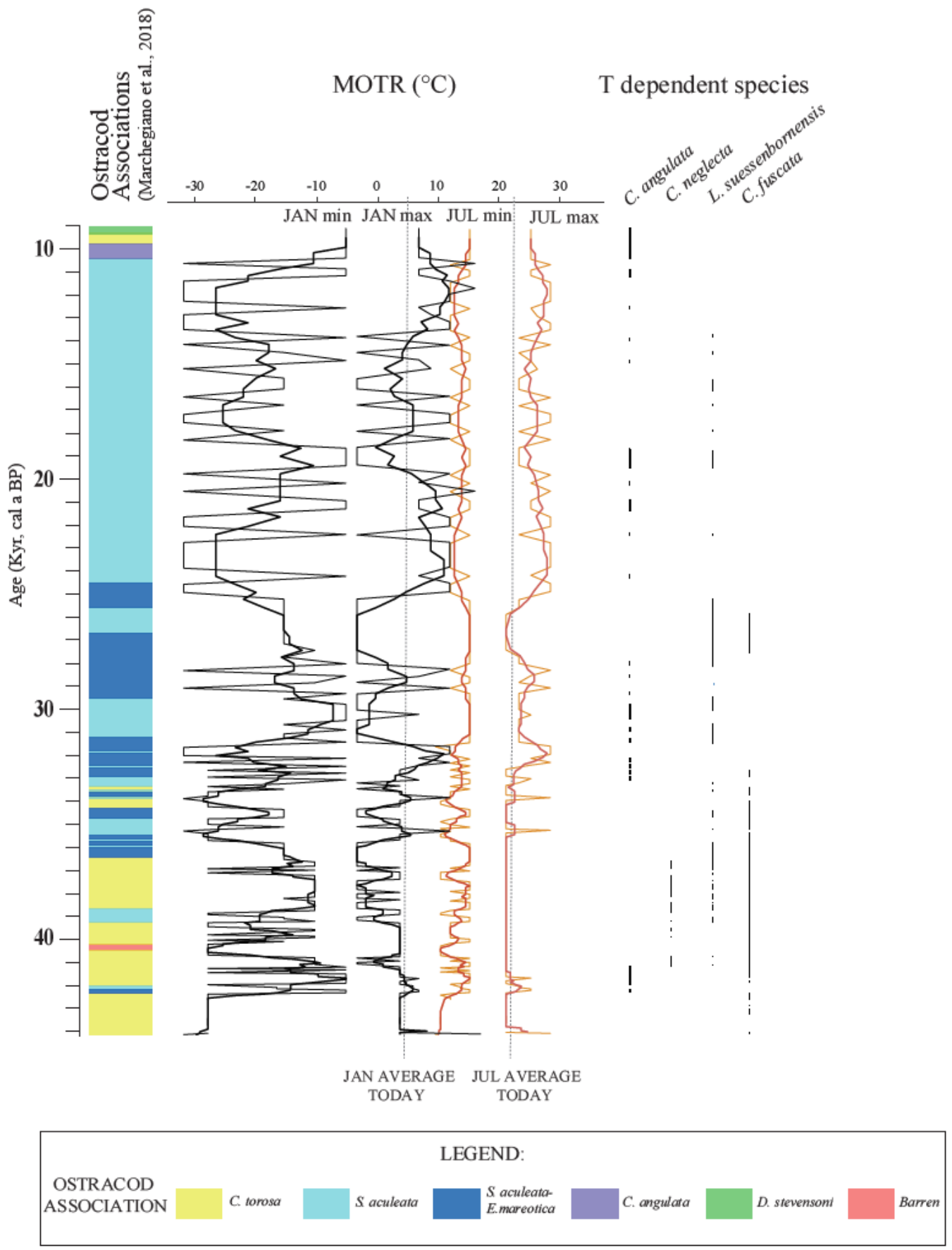

FIG. 6: MOTR application along the Co1320 sediment core. From the left, the ostracod associations identified by Marchegiano et al. (2018), the four MOTRderived curves (thicker curves represent the five-point moving averages), the main temperature dependent species significant in determining the MOTR and the interval separation (refer to the main text). 
TABLE 1. Ostracod species recovered in the Trasimeno sediment core and the calibrated mean January and July air temperature ranges for species used in the MOTR method application.

\begin{tabular}{llll} 
Species & July & & Jan \\
\hline \multicolumn{1}{l}{ Mmnicythere sp } & Min $\left({ }^{\circ} \mathrm{C}\right)$ & $\operatorname{Max}\left({ }^{\circ} \mathrm{C}\right)$ & Min $\left({ }^{\circ} \mathrm{C}\right)$ \\
Candona (Neglecandona) angulata G.W. Müller & - & - & - \\
Candona (Candona) candida O.F. Müller & 6 & 25 & -5 \\
Candona (Neglecandona) neglecta Sars & 7 & 26 & -40 \\
Cypridopsis vidua (O.F. Müller) & 9 & 27 & -10 \\
Cytheromorpha fuscata (Brady) & 10 & 34 & -32 \\
Cyprideis torosa (Jones) & - & - & -27 \\
Darwinula stevensoni (Brady \& Robertson) & 12 & 30 & - \\
Eucypris mareotica (Fischer) & 6 & 28 & -31 \\
Herpetocypris helenae G.W.Müller & - & - & - \\
Heterocypris incongruens (Ramdohr) & 5 & 28 & -31 \\
Heterocypris salina (Brady) & 8 & 28 & -31 \\
Ilyocypris bradyi Sars & - & - & - \\
Limnocythere inopinata (Baird) & 12 & 34 & -32 \\
Limnocythere suessenbornensis Diebel & 16 & 23 & -15 \\
Plesiocypridopsis newtoni (Brady \& Robertson) & 12 & 27 & -31 \\
Potamocypris paludum Gauthier & - & - & - \\
Sarscypridopsis aculeata (Costa) & 9 & 28 & -31 \\
Trajancypris serrata (G.W. Müller) & - & - & - \\
\hline
\end{tabular}

